SECTION 29. Literature. Folklore. Translation Studies.

Darya Gennadievna Manzhos teacher, Federal State Budget Educational Establishment Initial Professional Education Professional College № 81, Post-graduate student of Taganrog Institute named after A.P. Chekhov (branch) of Rostov State University of Economics, Russia oks.marunevich@mail.ru

\title{
THE PECULIAR FEATURES OF THE CONCEPT TEUFEL REPRESENTATION IN PROVERBS AND SAYINGS IN GERMAN LANGUAGE
}

Abstract: The article discusses the peculiarities of constructing the devil's image by native German-speakers based on adages and sayings. Devil's perception as the incarnation of the world's evil has its roots in the Middle Ages and earlier due to the active spread of Christianity in German lands. Analysis of linguistic material suggests that in the minds of naive evaluation of the devil varies from acceptably negative to arch negative.

Key words: concept, linguistics, culture, adage, mythological view, superstitions, naïve view.

\section{ОСОБЕННОСТИ РЕПРЕЗЕНТАЦИИ КОНЦЕПТА ТЕUFЕL В ПАРЕМИОЛОГИЧЕСКОМ ФОНДЕ НЕМЕЦКОГО ЯЗЫКА}

\begin{abstract}
Аннотация: В статье рассматривается специфика конструирования образа дьявола носителями немецкой лингвокультуры на основе пословичного фонда. Восприятие дьявола как воплощения мирового зла уходит корнями в ранее Средневековье и связано с активным распространением христианства в немецких землях. Анализ языкового материала свидетельствует о том, что в наивном сознании оценка дьявола варьируется от сверх негативного до приемлемо негативного.
\end{abstract}

Ключевые слова: концепт, лингвокультура, паремия, мифологическое мировоззрение, суеверия, наивное сознание.

Возможными стратегиями описания базовых концептов культурно-языкового сознания в рамках лингвокультурологического подхода являются как представление отдельных концептов на основании всего потенциала фоновых знаний носителей языка, зафиксированных в устной и письменной культуре, так и описание тех или иных концептов на конкретном языковом материале.

Для описания концепта Teufel нами был избран второй поход, что позволяет получить данные о немецкой картине мира на основе «анализа семантически цельного фрагмента языковой и культурной традиции, которым являются пословицы» [1, с. 152].

Паремиологические единицы аккумулируют в себе народную мудрость, фиксируют традиционную картину мира народа и осуществляют межпоколенную трансляцию культуры. Как пишет А. Дандис, наряду с другими формами культуры они являются «автобиографией народа», «зеркалом культуры» [7, р. 38].

В связи с этим, пословицы отражают жизнь народа, как современную, так и историческую, знакомят нас с суевериями, представлениями об окружающем мире, людях, отношении к ним. В пословицах о нечистой силе можно проследить следы: мифологического мировоззрения, исторических событий, церковно-христианского учения, народного творчества.

Связь времен прослеживается, например, в таких выражениях, как Thunaer endi Uuoden, zum Donner und Teufel (XIX в.) и в современных Donner und Blitz, Donner und 
Doria. В них присутствуют: Uuoden - верховный германский бог, громовержец Donner и присущий христианской эпохе Teufel. Donner und Blitz, Donner und Doria употребляются сегодня в языке параллельно, имеют помету «разг.». Элемент Doria литературного происхождения. Это перифраза одного из героев Ф. Шиллера из «Заговора Фиеско в Генуе». Выражения Thunaer endi Uuoden, zum Donner und Teufel иллюстрируют тесную связь язычнического и христианского мировосприятия. Доказательством тому является замена компонента Uuoden на компонент Teufel.

Мифологический сюжет с языческим богом-громовержцем породил множество других поведенческих и языковых стереотипов, мотивированных как на самом этом образе, так и на атрибутике этого божества. Дальнейшая их роль в немецком языке особенно ярко проявилась в период Средневековья, в эпоху переосмысления многих древних явлений, символов, обычаев [8, p. 125]. Множество примеров тому можно найти в языке позднего Средневековья.

Так, Донар появляется на колеснице, запряженной двумя козлами. При таком видении произносили: Donners Blosken help! (Donners blauer Schein hilf) [10]; cp.: blau pfeifen «hexen», blaues Wunder «Teufelsstück». Из-за рогатых животных, запряженных в его повозку, Донар назывался также Bock, что в дальнейшем стало эвфемизмом для Teufel. Зло также обозначалось в Средние века словом hellebock, Höllenbock. С этим же связано и неоднократно зафиксированное в письменных литературных памятниках с XVI в. употребление проклятий Daß dich der Bock schände! или Boxhorn soll dich schänden! Аналогичные речевые стереотипы известны сегодня и в диалектах, например, шваб. Daß mich der Bock stoße! или Bock, streck mich! [9, s. 16]. Одним из атрибутов Донара является молот (Hammer), благодаря чему становится понятным компонент schlagen в выражениии Da schlag der Teufel zu! Cp.: Da schlag doch der Teufel drein [10].

В древневерхненемецком и в последующие периоды диалектное Gauch обозначало кукушку, являвшуюся посланником Донара. Gauch также имеет значение Schelm, Betrüger, что в свою очередь представляет собой одну из характеристик этого зловещего существа. Примечательно, что этимологически слово Teufel заимствовано из латыни и восходит к греческому diabolus - клеветник [3, с. 107]. Сp.: Geh zum Kuckuck! Hol dich der Kuckuck! Das weiss der Kuckuck! Употреблялось также и в значении das Böse, das Teuflische [6].

В одном из фастнахтшпилей Г. Сакса хозяин обращается к долго отсутствовавшему, провинившемуся слуге с фразой: Wohl 'rein, in Henkers Namen 'rein! [2, c. 11]. Компонент Henker, непонятный на первый взгляд, имеет происхождение, полностью объясняющее его присутствие в данной фразе. В некоторых выражениях вместо Teufel употребляется Henker - средневековый судья-палач, который, как и Teufel, имеет прозвище Meister Hämmerlein. Возможно, как предполагает И. Цельтер, это связано и с Hinker - так эвфемистически называли нечистую силу [10]. Понятия Henker и Hinker слились в сознании человека, передавая страх, который он испытывает перед этим существом.

Отдельный пласт лексики - восклицания-проклятия идиоматизированного характера, многие из которых сохранились до наших дней. В современном немецком языке это такие выражения как: bist du des Teufel? - ты спятил?, hole dich der Teufel, der Teufel soll dich holen - черт тебя подери!, zum Teufel gehen, sich zum Teufel scheren - идти к черту. В некоторых случаях употребление эмфатитической идиомы с компонентом Teufel является перформативным закреплением конфиденциальности, имплицирующим сему «тайна»: der Teufel soil mich holen, wenn ich etwas weitersag.

Анализ паремиологического фонда немецкого языка показал, что помимо религиозной составляющей etwas fürchten wie der Teufel das Weihwasser - бояться как черт святой воды, womit scherzt der Teufel nicht, solange Gott schlaft - чем черт не шутит, пока Бог спит, среди характеристик черта чаще всего преобладает его связь с деньгами, властью и богатством: Dem Freigebigen gibt Gott, den Geizigen bestiehlt der Teufel - Щедрому дает бог, скупого обкрадывает черт; Wer Geld hat, dem geht der Teufel aus dem Wege. - Кто имеет 
деньги, тому чёрт не помеха; Für Geld lässt man den Teufel tanzen. - Из-за денег заставляют чёрта танцевать.

Пословица Der stinkt nach Geld wie der Teufel nach Weihrauch - он воняет деньгами, как черт ладаном - построена на парадоксальном сравнении. Черт боится ладана, поэтому в поговорке имеется в виду человек, у которого нет денег. Кстати, для выражения сочувствия, жалости человеку также широко используется выражение с Teufel: armerTeufel - бедняга.

В целом, что не удивительно, черту приписываются исключительно отрицательные характеристики. Во-первых, он медлителен: Der ist schon auf, ehe der Teufel seine Schuhe anhat, на литературном языке в таком случае говорят: er ist ein fixer Junge. В данном примере фигурирует мальчик, который настолько быстр, что он уже встал, опередив черта, а черт еще надевает свою обувь. Во-вторых, черта следует опасаться всем добропорядочным людям во избежание опасности: Dem Teufel in den Rachen laufen. In Teufels Küche kommen / greaten - попасть в неприятное положение; den Teufel auf den Hals laden - попасть в неприятности; Hat der Teufel erst einen Finger, dann kriegt er auch die Hand, enn man dem Teufel den kleinen Finger gibt, so nimmt er gleich die ganze Hand - дай дьяволу палец, он возьмет всю руку; Wer mit dem Teufel frühstücken will, muss einen langen Löffel haben. - Хочешь завтракать с чертом - припасай длинную ложку! Как писал Б. Брехт, Aber was soll ich sagen, der Teufel mochte seine schwarze Hand im Spiel haben, es kann keine rechte Stimmung auf [5, s. 190].

Не стоит упоминать имя дьявола всуе: Wenn man vom Teufel spricht, dann kommt er gelaufen - Когда заговаривают о чёрте, то тот бегом прибегает; Wen man den Teufel an die Wand malt, kommt er - нарисуй черта, он и появится, отсюда произошел разговорный глагольный оборот - den Teufel an die Wand malen - рисовать всякие ужасы.

В ряде паремий указывается на традиционное местопребывание нечистой силы: wenn es nur ein Moor gibt, dann finden sich auch die Teufel - было бы болото, а черти найдутся; im stillen Teich (Sumpf) gibt es Teufel - в тихом омуте (болоте) черти водятся.

Следует подчеркнуть, что болото является место жительства не только немецких чертей. Например, по верованиям, засвидетельствованным у восточнославянских народов, злые духи получили свои имена по тем местам, куда они попали, будучи сброшенными с неба. Те из них, что упали в болото или реку стали называться водяными, в лес - лешими; те, что свалились на дома - домовыми [4]. Также дело обстояло и в других языках, в чешском: skalní muž - горный муж, skalní človíček - горный человечек, vodník - водяной.

Иногда местом обитания нечистой силы является сам человек - j-n reitet der Teufelв кого-то вселился бес.

Не смотря на то, что черт - это олицетворение зла, в немецких паремиях и устойчивых выражениях указывается, что он совсем не страшен людям: weder Tod noch Teufel fürchten - не бояться черта; Der Teufel ist nicht so schwarz, wie man ihn malt - Не так страшен черт, как его малюют. Чего не скажешь о его внешности: Lange Nas' und spitzes Kinn // Da sitzt der Satan leibhaft drin - Длинный нос и острый подбородок, // Это сатана собственной персоной. Данное двустишие известно на территории всей Германии, Австрии, Швейцарии и Голландии и заключает в себе антиэталон внешности. Самое первое употребление этого двустишия зафиксировано в 1565 г. и относится к турниру, на который рыцари приходили переодетыми и в масках, которые комментировались словами: Spitzig Nasen, helle Stimmen, Wohnt der Teufel darinnen - Острые носы, светлые волосы, в них живёт чёрт.

Кроме того, в паремиях можно найти указание на своеобразную «иерархию» нечистой силы: Den Teufel treibt man mit Beelzebub aus (букв. изгонять беса Вельзевулом).

Вместе с тем в немецком языке фиксируется значительное количество паремий, где компонент Teufel - лишь инструмент для иллюстрации каких-то общечеловеческих, бытовых тем: 
Wird der Bart grau, stößt der Teufel in die Rippe - седина в бороду, бес в ребро. Так говорят о пожилом мужчине, который начинает активно интересоваться женщинами.

Der Teufel läßt keinen Schelmen sitzen - ворон ворону глаз не выклюет.

Alles nimmt der Teufel, nur ein boeses Weib nicht - злой бабе и черт не страшен. Ср. в русском языке - Куда черт не поспеет, туда бабу пошлет. Злой мужик - как черт, а злая баба - как целое пекло. В воронежских говорах чертом называют женщин, отличающихся скверным характером. Этическая оценка, содержащаяся в данной паремии, основана на ассоциациях, которые вызывает нечистая сила. Добро всегда исходит от Бога, тогда как зло - это происки дьявола, поэтому злой человек также называется ein leibhaftiger Teufel сущий дьявол, ср. в английском языке a limp of the devil; den Teufel im Leibe haben - иметь дьявольский темперамент. Интересно, что в сознании носителя немецкого языка черт является ближайшим родственником жены - der Frau Mutter ist des Mannes Teufel, букв. мать жены - чертова мама. И если человек однажды встал на строну зла, то ему всегда сопутствует удача, потому что der Teufel hilft seinem Volk - Дьявол помогает своему народу.

Таким образом, оценка черта как представителя и олицетворения вселенского зла носителями немецкого языка в значительной степени обусловлена влиянием Средневековья. Персонификация зла в образе черта, дьявола или другой нечистой силы согласно христианским догмам не случайна. Прежде всего, он - антагонист всемогущего Бога. Но с другой стороны анализ языкового материала показывает, что восприятие Teufel в наивном сознании имеет широкий диапазон: от сверх негативного до приемлемо негативного.

\section{References:}

1. Жданова В.В. Пословицы и поговорки как источник изучения русского культурноязыкового сознания // Культурные слои во фразеологизмах и дискурсивных практиках / Отв. ред. В.Н. Телия. М.: Языки русской культуры, 2004. С. 151-161.

2. Нифонтова Д.В. Речевые стратегии и тактики диалога в фастнахтшпилях Ганса Сакса. Автореф. дис. ... канд. филологич. наук, СПб., 2012.

3. Словарь инфернальной мифологии Средневековья. М.: Интрада, 1998.

4. Токарев С.А. Религиозные верования восточнославянских народов XIX-начала XX века. М.: УРСС, 2012.

5. Brecht B. Geschichten vom Herrn Keuner. GRIN Verlag, 2013.

6. DeutschesWörterbuch von Jacob und Wilhelm Grimm. 16 Bde. Leipzig: S. Hirzel 18541960.

7. Dundes A. On the Structure of the Proverb // Proverbium. 1975. № 25.

8. Marunevich O.V., Manzhos D.G. The Methods and Forms of Folk's Naive Views Archiving about Devil as a Foreigner in the English and Russian Folklore in XVII-XIX Centuries // The Strategies of Modern Sciebce Development. III International Scientific Conference. Science Book Publishing House, Yelm, 2013.

9. Röhrich L. Lexikon der sprichwörtlichen Redensarten. Freiburg, Basel, Wien: Herder, 1973.

10. Zelter J.Deutsche Sprache und deutsches Leben. Arnsberg: Stahl, 1907. 